Acta vet. scand. $1987,28,93-104$.

From the Department of Pathology, National Veterinary Institute, Uppsala and the Department of Farm Buildings, Swedish University of Agricultural Sciences, Lund, Sweden.

\title{
Histomorphological Studies of the Perinatal Pig: The Unaffected Pig
}

\author{
By $N$-E. Björklund, J. Svendsen and L.S. Svendsen
}

\begin{abstract}
Björklund, N-E., J. Svendsen and L. S. Svendsen: Histomorphological studies of the perinatal pig: the unaffected pig. Acta vet. scand. 1987, 28, 93-104. - In an attempt to further elucidate the causes of perinatal mortality in pigs, a histomorphological study of organs from normal 0.4 to $60 \mathrm{~h}$ old euthanized piglets and from perinatal dead/euthanized pigs belonging to different mortality groups was performed. The heart, lung, liver, kidney, spleen, thymus, pancreas, thyroid and adrenal glands were studied; all sections were examined without previous knowledge of the cause of death. Different observations in the organs were judged according to a scale of 1 to 4 where $1=$ none or significant and $4=$ a high degree of specific organ characteristics. The percentage of the group examined that scored 3-4 was calculated for each organ characteristic, and with the help of covariance analysis adjusted for the linear effect of total body weight (at the time of death), age, gestation length, and litter size (all pigs born, alive or dead). This first report describes the observations for the euthanized normal animals.
\end{abstract}

histomorphological characteristics; organs; perinatal period.

\section{Introduction}

Available statistics from many countries show that approximately $20 \%$ of the pigs born die before weaning (Gracey 1955, Anon. 1959, Pomeroy 1960, Kernkamp 1965, Jacobsen 1972, Leman et al. 1972, Bäckström 1973, Nielsen et al. 1974). Most of these death losses occur during the period immediately before, during and 2-3 days after birth, that is, the perinatal period (Svendsen \& Bille 1981). Post mortem examination of pigs dying during the perinatal period show that several "mortality" groups may be identified (Bille et al. 1974). One approach to the understanding of the causes of these losses is to determine the characteristics of the pigs in each of the mortality groups and, if possible, compare them.
Therefore, 5 mortality groups were identified on the basis of clinical and post mortem studies: stillborn intra partum (i.p.) pigs, weak and/or undersized pigs, splayleg pigs, splayleg and weak (splayweak) pigs, and traumatized pigs (Svendsen 1982). Histomorphological characteristics of these pigs and apparently normal euthanized littermates $0.4-60 \mathrm{~h}$ of age have been studied.

This paper presents data from a semiquantitative histomorphological examination of organs from the newborn, normal pig, and the litter factors influencing these observations. In a subsequent paper, the histomorphological picture of these apparently normal pigs will be compared to that of the perinatal dead pigs in the mortality groups (Björklund et al. 1987). 
Materials and methods

Animals and housing

All animal material was obtained from a herd of 90 pure breed Swedish Landrace sows, during the period 1978-1983. Complete management, health and production data for the sows and their offspring were maintained, and the herd was under continual veterinary supervision. The sows were maintained either fixed in stalls or loose in pens during the gestation period, and moved to the farrowing area 3-5 days before expected farrowing. No health problems were seen among the dry sows which could affect the litter. The feed ration for sows was purchased complete (Lantmännens Suggfor, Sweden), and contained approximately $13 \%$ raw protein. Pregnant animals in good condition received about $2.2 \mathrm{~kg} /$ day, whereas those in poor condition and all sows from about 90 days gestation received about 3.2 $\mathrm{kg}$ /day. Suckling piglets were offered an iron glutamate solution (Fe-Max, Peter Möller, Norway) from the first day of life, and dry food (Pigolact, Lantmännen, Sweden) from day 3 after birth. For details concerning feeding, general husbandry procedures and housing systems for sows and piglets see Jeppsson et al. (1980), Svendsen \& Bengtsson $(1982,1983)$ and Bengtsson et al. (1983).
Twenty-eight apparently normal, vigorous pigs (21 suckled, 7 unsuckled) (Randall 1971, DeRoth \& Downie 1976) from 23 litters were used in this part of the study. Production data with respect to this group are shown in Table 1. Piglets dying during the perinatal period and judged as belonging to one of the mortality groups were also collected for examination, but the characteristics of these groups will be described in the subsequent paper (Björklund et al. 1986).

\section{Histomorphological examinations}

The piglets were euthanized by bleeding from the axillary vein at various times within $0.4-60 \mathrm{~h}$ after birth (Table 1). Post mortem examination was performed immediately after death. The brain, lungs, liver, heart, kidneys, thyroid, pancreas, spleen, thymus and adrenals were weighed (Svendsen 1982) and fixed in neutral formalin or in absolute alcohol for histological examinations. The following routine staining methods were used for the paraffin embedded sections: hematoxylin-eosin (H. E.), van Gieson and PAS before and after diastase treatment. Occassionally, Best's carmine staining for glycogen, and Gomori's method for reticulum were done. Certain sections of pancreas were stained with a triple stain for simultaneous visualization of cell types in

Table 1. Description of animal material; production data for unaffected pigs.

\begin{tabular}{lcrr}
\hline & Number & Mean & Range \\
\hline Number of pigs & 28 & & \\
No. litters & 23 & & \\
Litter size & & 10.9 & $3-17$ \\
Gestation length (days) & & 114.9 & $112-117$ \\
Age (h) & & 20.7 & $0.4-60$ \\
Males:females (\%) & $68: 32$ & & \\
Weight (g) & & 1297 & $850-1780$ \\
\hline
\end{tabular}


the islets of Langerhans (Kito et al. 1977). For detection of lipid substances, frozen sections were stained with scarlet red and Oilred-0.

\section{Statistical analyses}

For the entire study, all sections were examined without previous knowledge of the cause of death. The different histological pictures were judged according to a scale from $1-4$, where 1 = none or insignificant, and $4=$ a high degree of a specific organ characteristic. The percentage of the group examined judged as having a score of $3-4$ was calculated for each organ characteristic.

Using statistical programs taken from the BMDP-Biomedical Computer Programs, Pseries (Dixon \& Brown 1979), the mean score for each organ characteristic was adjusted for the linear effect of the independent variables, total body weight (at the time of death), age, gestation length, and litter size (all pigs born, alive or dead), with the help of covariance analysis. The per cent changes in the individual mean scores after adjustment for the linear effect of the independent variables was used to adjust the group percentages for the specific organ characteristic. Partial correlation analysis, where correlation coefficients can be determined between different variables after removing the linear effects of the independent variables, was used to evaluate:

a. The amount of variation in the specific organ characteristics that could be accounted for by the individual independent variables, and the regression equation containing the independent variables;

b. the significance of a;

c. the correlation between the specific organ characteristics and the adjusted organ weights.
Adjusting organ weights and organ characteristics for the linear effects of body weight, age, gestation length and litter sizes results in a standardization; this represents the organ weight (or organ characteristics) which the pigs in the group would have had, if their growth (or organ characteristics) had not in some manner been affected by the independent variables. This enables comparisons to be made between the different mortality groups described in the following paper (Björklund et al. 1987).

\section{Results}

A summary of the histomorphological observations for specific organ characteristics and the litter factors influencing these observations is presented in Table 2, together with adjusted organ weights.

The brain, as a rather complicated organ is at present under special study, and the results will be presented at a later date. With the histological methods used in this study no specific morphological changes were observed in the heart differing from those of older animals. Therefore, the results were not included in Table 2.

\section{Lungs}

The mean adjusted lung weight was $16.7 \mathrm{~g}$ (Table 2). The bronchiolar epithelium consisted to a great extent of cells having a vacuolar cytoplasm (Fig. 1), with no or only a narrow irregular band of $\mathrm{H}$. E. stainable cytoplasm. Sometimes, the bronchiolar epithelium appeared hyperplastic. Areas of atelectasis with or without bronchiolar contractions were present in about $50 \%$ of the cases (Table 2). The occurrence of hyperplastic epithelium and bronchiolar contractions appeared to increase with age (Table 2). Otherwise, the lungs of newborn pigs did 
Table 2. Histomorphological and organ weight observations of the organs of the organs of 28 unaffected pigs.

\begin{tabular}{|c|c|c|c|c|c|c|c|c|}
\hline \multirow[t]{2}{*}{ Organ characteristics } & \multicolumn{2}{|c|}{$\begin{array}{l}\% \text { pigs with a high degree } \\
\text { of specific organ } \\
\text { characteristics }\end{array}$} & \multicolumn{4}{|c|}{ Influence of litter factors ${ }^{3}$} & \multirow{2}{*}{$\begin{array}{l}\text { Adjusted }^{4} \\
\text { organ } \\
\text { weight } \\
\text { B }\end{array}$} & \multirow{2}{*}{$\begin{array}{l}\text { Correlation } \\
\text { with adj. } \\
\text { organ } \\
\text { weight }\end{array}$} \\
\hline & Unadjusted $^{1}$ & Adjusted $^{2}$ & Age & $\begin{array}{l}\text { Gest. } \\
\text { length }\end{array}$ & $\begin{array}{l}\text { Litter } \\
\text { size }\end{array}$ & $\mathrm{r}^{2}$ & & \\
\hline $\begin{array}{l}\text { Lungs: } \\
\text { - hyperplastic bronchiolar } \\
\quad \text { epithelium } \\
\text { - bronchiolar contraction } \\
\text { - atelectasis } \\
\text { - hyperemia } \\
\text { - edema }\end{array}$ & $\begin{array}{r}12 \\
20 \\
48 \\
8 \\
16\end{array}$ & $\begin{array}{r}13 \\
22 \\
52 \\
7 \\
14\end{array}$ & $\begin{array}{l}\text { inc** } \\
\text { inc* } \\
\operatorname{dec}^{+}\end{array}$ & $\begin{array}{l}\operatorname{dec}^{+} \\
\operatorname{dec}^{*}\end{array}$ & inc* & $\begin{array}{l}.54^{* *} \\
.37^{*} \\
.35^{+} \\
.41 \\
.35^{+}\end{array}$ & 16.72 & .49 \\
\hline $\begin{array}{l}\text { Liver: } \\
\text { - connective tissue in } \\
\text { portal spaces } \\
\text { - occurrence of immature cells } \\
\text { - cellular lipids } \\
\text { - cellular glycogen } \\
\text { - hyperemia } \\
\text { - patchy irregularities in } \\
\text { liver structure } \\
\text { - extramedullary hematopoiesis }\end{array}$ & $\begin{array}{l}11 \\
50 \\
63 \\
43 \\
25\end{array}$ & $\begin{array}{l}11 \\
44 \\
61 \\
43 \\
22\end{array}$ & $\begin{array}{l}\operatorname{dec}^{*} \\
\operatorname{dec}^{* * * *}\end{array}$ & $\operatorname{dec} * *$ & & $\begin{array}{l}.46^{* *} \\
.41^{*}\end{array}$ & 33.74 & \\
\hline $\begin{array}{l}\text { Kidneys: } \\
\text { - cortical hyperemia and } \\
\text { bleeding. } \\
\text { - medullary hyperemia } \\
\text { - medullary edema } \\
\text { - degenerative changes in } \\
\text { convoluted tubules }\end{array}$ & $\begin{array}{r}24 \\
20 \\
28 \\
4\end{array}$ & $\begin{array}{l}22 \\
18 \\
28 \\
4\end{array}$ & inc $^{+}$ & & inc* & $.45^{*}$ & 9.10 & -.48 \\
\hline $\begin{array}{l}\text { Spleen: } \\
\text { - No. Malpighian follicles } \\
\text { - extramedullary hematopoiesis }\end{array}$ & $\begin{array}{l}5.0 \\
45\end{array}$ & $\begin{array}{l}4.7 \\
48\end{array}$ & & & & & 1.16 & -.43 \\
\hline $\begin{array}{l}\text { Thymus: } \\
\text { - cortical atrophy } \\
\text { - interlobulary edema } \\
\text { - No. Hassall's corpuscles } \\
\text { - extramedullary hematopoiesis }\end{array}$ & $\begin{array}{c}30 \\
13 \\
3.1 \\
13\end{array}$ & $\begin{array}{c}28 \\
12 \\
3.1 \\
13\end{array}$ & inc $^{+}$ & & $\begin{array}{l}\text { dec** } \\
\text { dec }^{* * *}\end{array}$ & $\begin{array}{l}.44^{+} \\
.65^{* * *} \\
.42^{+}\end{array}$ & 3.98 & $\begin{array}{r}.49 \\
-.35\end{array}$ \\
\hline $\begin{array}{l}\text { Pancreas: } \\
\text { - poor development of } \\
\text { - glandular tissue } \\
\text { - interlobulary edema } \\
\text { - degenerative nuclear } \\
\text { epithelial changes } \\
\text { - islets of Lagerhans }\end{array}$ & $\begin{array}{l}36 \\
40 \\
44 \\
28\end{array}$ & $\begin{array}{l}36 \\
42 \\
46 \\
27\end{array}$ & $\operatorname{dec}^{*}$ & & inc* & 30 & 1.51 & \\
\hline $\begin{array}{l}\text { Thyroid: } \\
\text { - vacuoles in follicular colloids } \\
\text { - interfollicular tissue with } \\
\text { clusters of epithelial cells } \\
\text { - colloid free follicles }\end{array}$ & $\begin{array}{l}52 \\
26\end{array}$ & $\begin{array}{l}55 \\
25\end{array}$ & & & & .34 & 0.20 & $\begin{array}{l}-.56 \\
-.45\end{array}$ \\
\hline $\begin{array}{l}\text { Adrenals: } \\
\text { - cortical lipids }\end{array}$ & 40 & 40 & ince* & $\mathrm{dec}^{* * *}$ & & $.60^{* * *}$ & 0.28 & \\
\hline
\end{tabular}

1 Expressed as a percentage of the pigs in the group that scored $3-4$ according to a scale of $1-4$, where $1=$ none or insignificant and $4=a$ high degree of the specific organ characteristic.

2 Mean scores for each organ characteristic, as in 1, adjusted for the linear effects of total body weight, age, gestation length and litter size, using covariance analysis; the percent change in mean score after adjustment for each specific organ characteristic was used to adjust the group percentages.

3 Multivariate regression using partial correlation analysis was used to determine the significance of the independent variables in ${ }^{2}$, and the amount of variation in the organ characteristic accounted for by the variation in the independent variables, as indicated by the $\mathrm{r}^{2}$ value $\times 100$, and the significance of the regression equation. Only those $\mathrm{r}^{2}$ values $\geq 0.30$ were given. $* * *=\mathrm{P}<0.001, * *=\mathrm{P}<0.01,{ }^{*}=\mathrm{P}<$ $0.05,{ }^{+}=\mathrm{P}<0.10$. Total body weight did not have a significant effect on the variation for this group of pigs.

4 Taken from Svendsen (1982).

5 Obtained using partial correlation analysis; only correlations $\geq 0.30$ are shown. 
$N$-E. Björklund, J. Svendsen and L.S. Svendsen: Histomorphological studies of the perinatal pig: The unaffected pig.
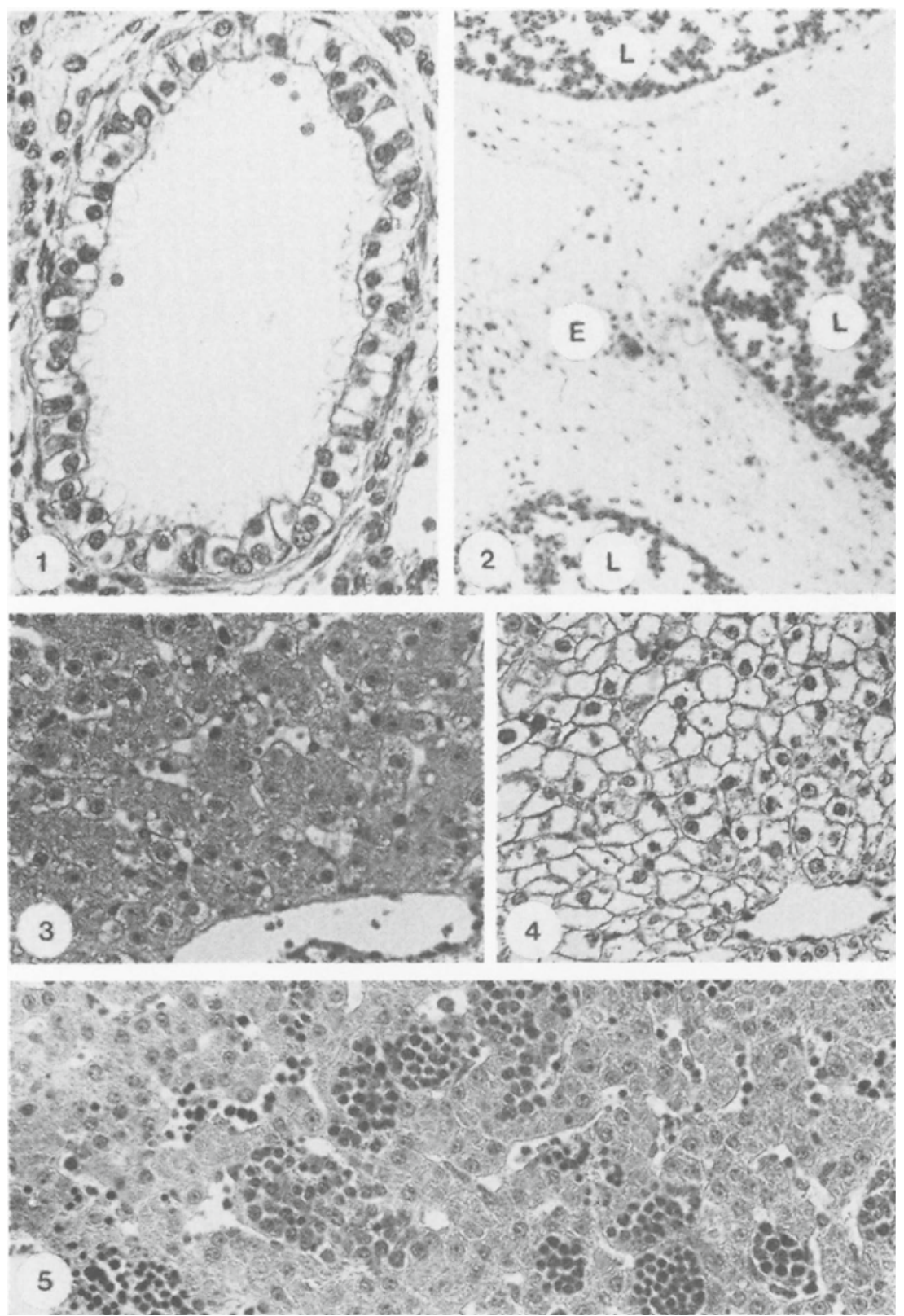

Figures 1 and 2. Lung tissue of newborn pigs. Vacuolated epithelium of a bronchiole (Fig. 1). Interlobular edema (E), (Fig. 2). L = Lobuli. H.E. stain, $400 \times$ (Fig. 1); $100 \times$ (Fig 2).

Figures 3, 4 and 5. Liver sections of 11,2 and $1 \mathrm{~h}$ old piglets, respectively. Apparently mature hepatocytes with evenly stained cytoplasm (Fig. 3) compared with large water-clear, immature cells (Fig. 4). Aggregates of hematopoietic cells in liver parenchyma (Fig. 5). H.E. stain, $250 \times$. 

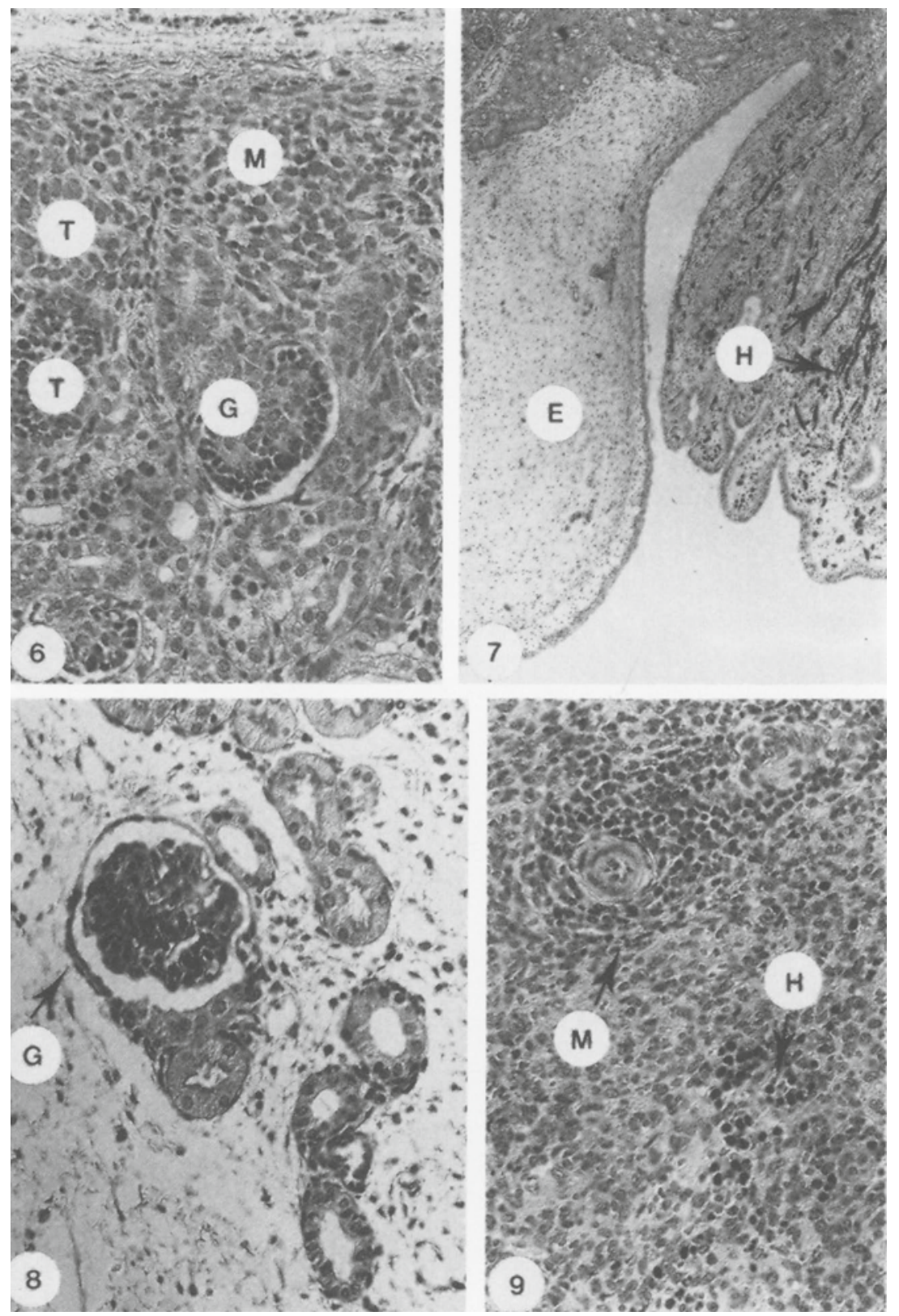

Figure 6. Kidney of a $2 \mathrm{~h}$ old piglet. Nephrogenic zone of the cortex with metanephric mesenchyme (M) and newly formed glomeruli $(G)$ and tubuli $(T)$. H.E. stain, $250 \times$.

Figures 7 and 8 . Medulla of the kidney of 3 and $30 \mathrm{~h}$ old piglets respectively. Papillary hyperemia $(\mathrm{H})$ and interpapillary edema (E) (Fig. 7). Glomerulus (G) in interpapillary edematous tissue (Fig. 8). H. E. stain, $40 \times$ (Fig. 7); PAS stain, $250 \times$ (Fig. 8). Figure 9. Spleen of a $2 \mathrm{~h}$ old piglet. Malpighian follicles (M) and clusters of hematopoietic cells $(\mathrm{H})$. H.E. stain, $250 \times$. 

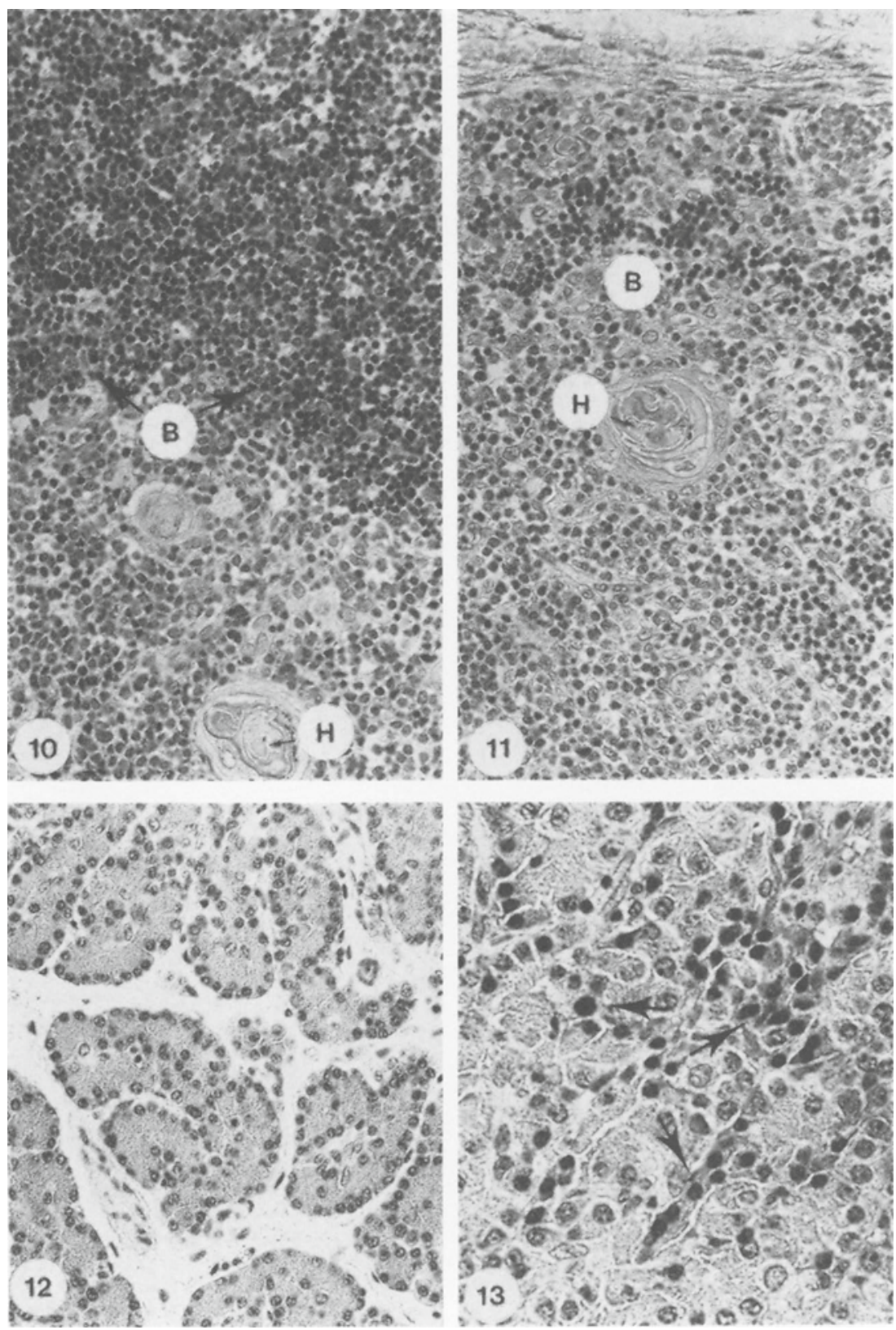

Figures 10 and 11 . Thymus of 8 and $42 \mathrm{~h}$ old piglets, respectively. Clear division (B) between normal cortex and medulla (Fig. 10). No distinct borderline (B) between small atrophic cortex with few lymphocytes and medulla (Fig. 11). $\mathrm{H}=$ Hassall's corpuscles. H.E. stain, $250 \times$.

Figures 12 and 13 . Exocrine pancreas of newborn and $21 \mathrm{~h}$ old piglets respectively. Lobulated normal gland tissue with interlobular edema (Fig. 12). Pyramidal cells packed together without distinct gland formation. Many cells with pyknotic nuclei (arrows) (Fig. 13). H.E. stain, $250 \times$ (Fig. 12); $400 \times$ (Fig. 13). 

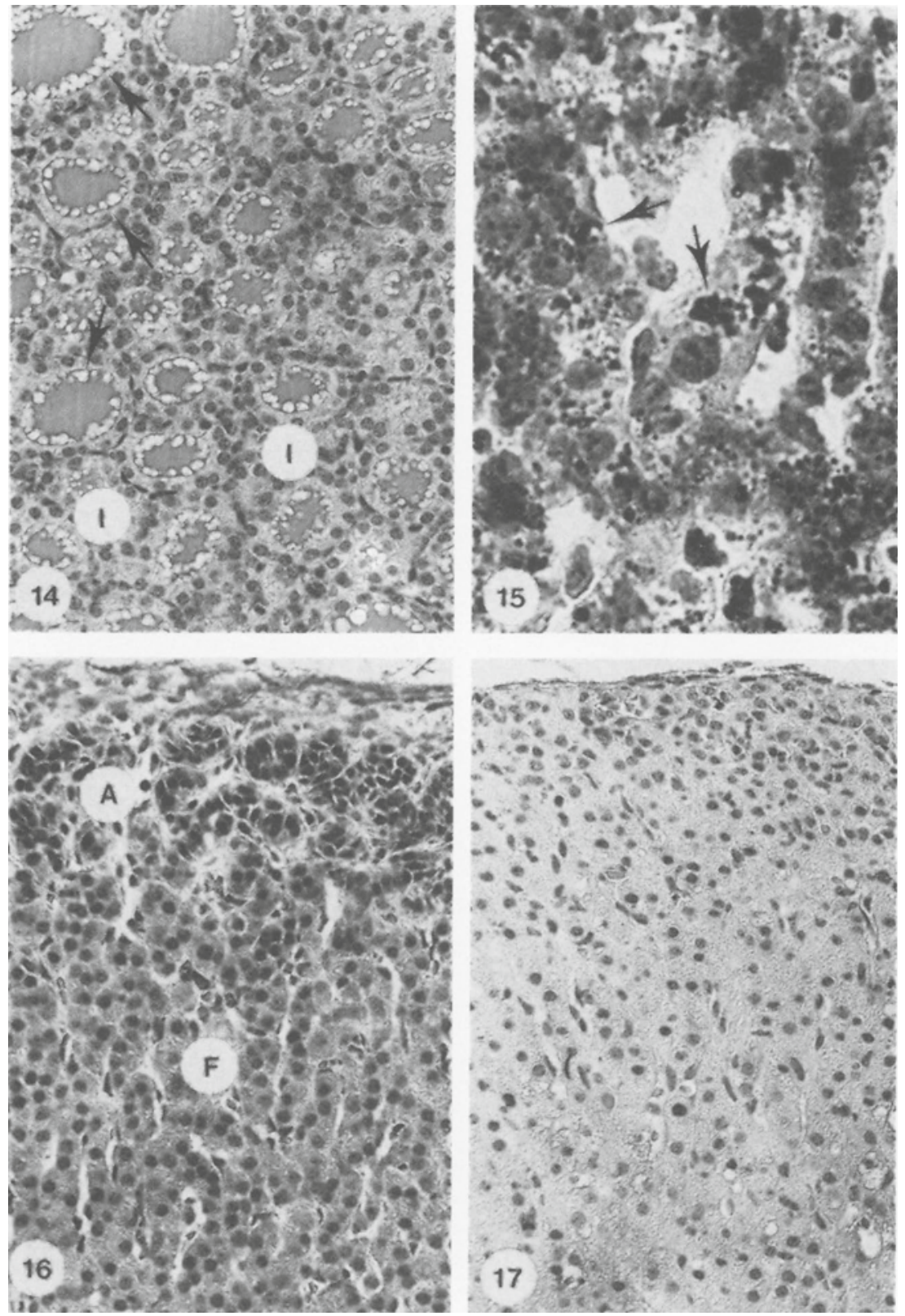

Figure 14. Thyroid of an $11 \mathrm{~h}$ old piglet. Vacuoles in colloid (arrows). Areas with interfollicular tissue (I). H.E. stain, $250 \times$.

Figures $15-17$. Adrenals of 24,3 and $17 \mathrm{~h}$ old piglets, respectively. Epithelial cells of zona fasciculata with lipid droplets (arrows) (Fig. 15). Well developed zona arcuata (A) and zona fasciculata (F) (Fig. 16). Diffuse borderline between these zones and poorly developed zona arcuata (Fig. 17). Oil-red-0 stain, $630 \times$ (Fig. 15); H.E. stain, $250 \times$ (Figs. 16 and 17). 
not differ greatly from what may be seen in the adult, with the exception that no intrapulmonary lymphoid tissue was detectable at any site on the lung. There was a varying degree of blood supply and hyperemia (Table 2). Bronchial, bronchiolar or alveolar edema was rare in this material; however, edema between the lobules was rather common. This edema was present in approximately $15 \%$ of the cases (Table 2, Fig. 2), and the incidence appeared to decrease with age.

\section{Liver}

The mean adjusted liver weight was $33.7 \mathrm{~g}$ (Table 2). Unlike adults, newborn pigs have no distinct hepatic lobules; the interlobular connective tissue still is very thin, and the portal spaces are small with a scanty occurrence of connective tissue containing young fibroblasts. Only $11 \%$ of the animals had distinct amount of connective tissue (Table 2). In most livers examined, large hepatocytes with water clear cytoplasm were present (Figs. 3, 4). More than a third of the hepatocytes had this appearance in $50 \%$ of the cases. As a result, the sinusoids in these areas appeared to be obliterated. These water clear "immature" liver cells did not react when stained for lipids or when stained with PAS; their occurrence decreased with age. However, lipids, in the form of small droplets in the cytoplasm, were observed in evenly stained hepatocytes. In more than 60 $\%$ of the animals, the amount present was estimated as moderate or high (Table 2) and tended to decrease with age. In addition, PAS-positive substances were frequently observed in "mature" cells. Since the staining reaction could be eliminated with diastase, these substances were considered to be glycogen (Table 2).

Approximately $25 \%$ of the livers were hyperemic. Sometimes, and usually in con- nection with hyperemia, small patchy areas of dilated sinusoids were present. These often had disrupted walls with dissolved liver cell cords and, in hyperemic livers, bleeding could be often observed (Table 2: Patchy irregularities in liver structure).

A prominent feature in the neonatal pig liver was the small aggregates of erythropoietic cells (Fig. 5). Eighteen per cent of the unaffected pigs had more than 4-6 aggregates per field of vision at $100 \times$ magnification (Table 2).

\section{Kidneys}

The mean adjusted weight of the kidneys was $9.1 \mathrm{~g}$ (Table 2). The pig is born with a prominent layer of undifferentiated tissue on the periphery of the kidney. This tissue consists of metanephric mesenchyme where the formation of new nephrons take place (Fig. 6). The thickness of this layer varied from case to case.

The cytoplasm of the proximal convoluted tubular epithelium often had a foamy, almost vacuolated appearance. Occasionally small patchy areas in the nephrogenic zone and other parts of the cortex had an appearance that indicated disturbances in development. Either the tubules in the nephrogenic zone were dilated, or the epithelium of the convoluted tubuli showed signs of vacuolar degeneration or hyalin drop degeneration. All these changes were termed nephrosis, and were seen in $4 \%$ of the apparently normal animals (Table 2).

In approximately $25 \%$ of the cases (Table 2 ), hyperemia and occasionally small points of bleedings could be distinguished in the cortex, usually more pronounced in the outer part. Hyperemia of the medulla was also observed in $20 \%$ of the pigs (Fig. 7). In almost one-third of the animals, edema was noted in the papillae between the collecting tubules or, more often, between the papillae 
in the loose connective tissue separating the renal medulla from the layers of transitional epithelium lining the renal pelvis (Fig. 7). Glomeruli of varying appearance could be seen in this edematous tissue (Fig. 8). These glomeruli were surrounded by only a few tubules or, in some cases, no tubules were visible at all.

\section{Spleen}

The mean adjusted spleen weight was $1.2 \mathrm{~g}$ (Table 2). The major difference between the newborn animals in this group and adult pigs was the poorly developed white pulp (Malpighian follicles) in the newborn (Fig. 9). Sometimes, there was only 1-2 layers of lymphocytes in various stages of maturation that could be observed around the central arteries. Germinal centres were not seen. The average number of follicles for 3 fields of vision at $100 \times$ magnification was 5.02 .

Erythropoietic cell nodules similar to those observed in the liver were often seen (Fig. 9). These were rather obvious in $45 \%$ of the pigs.

\section{Thymus}

The mean adjusted thymus weight was $4.0 \mathrm{~g}$ (Table 2). The thymus of the newborn pig was divided into lobes and lobules by a connective tissue in which edema occasionally was observed. In $13 \%$ of the pigs, this interlobar tissue contained clusters of cells which could be classified as extramedullary hematopoiesis. In $70 \%$ of the pigs, the lobules of the thymus showed a sharp division, with a cortex having myriads of uniform, densely packed, small lymphocytes, and a palestaining medulla (Fig. 10). The medulla contained varying amounts of Hassall's corpuscles. The average number for 3 fields of vision at $100 \times$ magnification was 3.13 (Table 2).
In $30 \%$ of the piglets, the amount of lymphocytes in the cortex was less numerous than in the other animals. The borderline between the cortex and the medulla was not as sharp, and parts of the network of cortical reticular cells could be seen (Fig. 11). This phenomenon was classified as atrophy of the cortex (Fig. 11) and its occurrence tended to decrease with litter size (Table 2).

\section{Pancreas}

The mean adjusted weight of the pancreas was $1.5 \mathrm{~g}$ (Table 2). The exocrine pancreas of the newborn pig resembled that of the adult. It was well lobulated and the acinar glands usually could easily be recognized, having pyramidal cells with a round basal nucleus (Fig 12). The zymogen granules in the apical cytoplasm were sometimes difficult to see. However, there were cases in which the normal acinar structure was not apparent in the entire pancreas or in parts of it. Instead of the pyramidal cells being arranged around the central lumen, they were packed together without gland formation (Fig. 13). Varying degrees of this picture were seen in $36 \%$ of the pigs (Table 2). On occasion, certain acinar cells had hyperchromatic (pyknotic) nuclei and in some cases, small foci with clumps of hyperchromatic nuclei practically devoid of cytoplasm were found. These were assumed to be degenerative epithelial changes and were observed in $46 \%$ of the unaffected pigs (Table 2).

In approximately $40 \%$ of the cases there was edema of the interlobular and/or intralobular tissue separating the lobes and lobules (Fig 12). This observation tended to decrease with age.

The endocrine pancreas or islets of Langerhans was often difficult to distinguish from the exocrine pancreas even when special staining methods were used. Therefore, in this investigation, we only roughly estimated 
the number of the islets, with a notation as being few, a moderate amount, or many. In $28 \%$ of the unaffected pigs, the amount was moderate or more.

\section{Thyroid}

The mean adjusted thyroid weight was $0.2 \mathrm{~g}$ (Table 2). The thyroid of the newborn pig had, like adult animals, follicles of varying size, which were lined with a cuboidal or slightly columnar epithelium. In most cases, the colloid stained only slightly with eosin. It was PAS positive, but the staining varied greatly in intensity. The colloid often had "vacuoles" of the types described by $\mathrm{An}$ dersson (1894) and Aron (1930) (Fig 14).

The number of colloid-containing follicles varied, from cases where the entire section consisted of follicles of differing size having scanty interfollicular tissue, to cases where the solid epithelial structures without luminae were rather prominent (Fig. 14). In the present material, the thyroids of approximately $50 \%$ of the pigs had a significant amount of this interfollicular tissue (Table 2). In $25 \%$ of the thyroids examined, a great number of the follicles were empty, while at the same time their epithelium was low, containing hyperchromatic pyknotic nuclei.

\section{Adrenals}

The mean adjusted adrenal weight was $0.3 \mathrm{~g}$ (Table 2). The histological picture of the adrenals resembled that of adult pigs. A socalled fetal cortex, which dominates a major part of the cortex in the early infancy of humans, was not seen. However, the zona arcuata was often poorly developed, with parts resembling the zona fasciculata (Figs. 16-17). The borderline between $z$. fasciculata and z. reticularis was usually diffuse. According to the staining methods used, the epithelial cells of the cortex contained lipid drops (Fig. 15), the number of which appa- rently increased with age and decreased with an increase in gestation length. However, only $40 \%$ of the pigs showed a significant amount of these substances (Table 2). The adrenal medulla of the newborn pigs resembled that of the adult.

\section{Discussion}

Systematic histomorphological studies of newborn, normal, food producing animals are scarce. The purpose of this investigation was to study the histomorphological picture and its variation in newborn, apparently healthy pigs, and some of the factors influencing this picture. In a subsequent paper (Björklund et al. 1987), the histomorphological organ changes in piglets dying during the perinatal period will be described and compared to that of the unaffected pig, in an attempt to elucidate factors which may contribute to the occurrence of perinatal losses in pigs. In addition to the organs reported in this study, the brain was also submitted for examination and will be described at a later time.

In several of the organs examined, edema and/or hyperemia was observed. Interstitial edema was a common observation in the lungs, kidneys, pancreas and thymus of uneffected, newborn pigs, and the incidence tended to decrease within the first 2-3 days of life. Interstitial as well as subcutaneous edema is sometimes seen in the fetal stage, and in pigs dying during the perinatal period. In addition, the tissues of pigs which die intra partum, and many weakborn pigs often appear moist. The cause and pathogenesis of this edema has been discussed (Edwards 1961, Coussement et al. 1983), but is still largely unknown. Edwards (1961) observed the significance of these findings in relation to the data on neonatal hypoproteinemia. Perhaps the interstitial edema observed in the newborn unaffected pig in this 
material represented traces of the fetal hemodynamic status, that is, represented an intermediate stage between fetal and extrauterine life. In the kidney, this edema was observed between the papillae of the medulla, and between the papillae and the pelvic mucosa. The presence of glomeruli in this edematous tissue (Fig. 8) has not been previously reported. These renal corpuscles did not appear to be functioning because only fragments or portions of the nephrons (tubules) could be detected. Many of these renal corpuscles appeared to be sclerotic.

Hyperemia was also observed in several of the organs studied, in particular in the liver and kidneys. Frequently, cortical hyperemia in the kidney was associated with small bleedings, the incidence of which appeared to increase with litter size (Table 2).

Almost $50 \%$ of the apparently normal, vital pigs in this material showed areas in the lungs which were described as atelectatic. Some of this atelectasis was probably due to remaining areas of congenital atelectasis; that is, represented areas of the lung which had not as yet been filled with air at birth. In other areas, it may have been an artifact, that is, an expression of high elasticity or contractability of the alveolar wall in a lung taken from an opened thorax (Valdés-Dapena 1979 , p. 335). High elasticity may also be the cause of bronchiolar contractions with age (Table 2). Thus, it is difficult to distinguish between congenital atelectasis and the histomorphological appearance of lung sections obtained from liveborn, normal pigs, when the lungs have been removed without taking precautions to avoid lung inflation. The difficulty of distinguishing the alveolar pattern in the human fetus at or near term, from the pattern seen in the newborn infant has been described by Shapiro (1977).

The appearance of bronchiolar cells with a vacuolar cytoplasm appeared to be another facet of the lung histology of the newborn. Such water clear cells were also observed in the liver and in the proximal convoluted tubules of the kidney. These cells appeared to be an expression of an immaturity that, in so far as the liver is concerned, has been documented by Bischoff et al. (1969), Hakkarainen (1975), and others.

According to Morrill (1952), Bischoff et al. (1969) and Glastonbury (1977) the water clear cells in the liver, the cells of the bronchii and the kidney apparently contain glycogen. However, no glycogen could be detected in the water clear cells of this material after fixation in formalin or in absolute alcohol. Either glycogen was not present, was very unstable and disappeared after the animal was euthanized, or was dissolved during the fixation process. Morill (1952) has pointed out the difficulties involved in retaining glycogen in tissues during histological procedures. Glycogen, however, could be detected in the dense "mature" and "normal" liver cells. These cells also contained lipid substances, an observation which decreased with age (Table 2). This observation appears at first to disagree with that of Hakkarainen (1975), who noted that the amount of glycogen in the liver decreases during the first 12 $\mathrm{h}$ of life, whereas the amount of fat increases, reaching a peak at $48 \mathrm{~h}$. However, he measured the total fat extractable from liver tissue, which is not the same as observing microscopically the number of lipid droplets in the cells, as in the present study. A slight fatty infiltration is normal in the liver cells of newborn children and animals, and has also been observed previously in the pig (Kühn \& Wesemeier 1984).

Another feature of the histology of the newborn pig is the presence of hematopoietic nodules in the liver and spleen, which has been documented by Miller et al. (1961), 
Glastonbury (1977), and others. Some clusters of these cells were also seen in the interlobular tissue of the thymus, similar to observations in humans (Valdés-Dapena 1979 , p. 57). The number of these hematopoietic clusters varied from case to case. According to Domenick \& Carson (1983), hypoxia occurring late in the fetal stage will lead to the release of erythropoietin by the kidneys, and this would stimulate multipotential stem cells to differentiate into erythropoietic precursors.

The newborn pig had a broad nephrogenic zone in the kidney (Fig. 6), where new nephrons develop. According to Friis (1980), the formation of new nephrons in the pig continues up to 3 weeks of age.

The histological picture of the spleen in this material agreed well with that observed by Glastonbury (1977). The small splenic follicles observed in these animals may be one of the signs of the "low immunological status" in the newborn pig, or may indicate that the spleen of the newborn pig has only a limited share of the body defence.

The histology of the thymus of the newborn pig has previously been studied by Waibl (1982). He observed that the thymic medulla in newborn pigs is proportionally larger, comprising $28.1 \%$ of the organ, than in both the fetus and pigs $2-4$ weeks of age, $18.7 \%$ and $20.2 \%$, respectively. In addition, the number of Hassall's corpuscles are greater in the newborn animal. The relatively small thymic cortex observed in the newborn was explained by Waibl (1982) as being a consequence of the high adrenal cortex activity before and after parturition. This may also explain the atrophy of the cortex noted in this paper (Table 2 and Fig. 11).

The adrenal cortex of newborn piglets is functionally mature and capable of ample response to stimulation by ACTH (Dvorak 1972). Adrenocortical activity develops in- tensively during the last 10 days of intrauterine life, and appears to be highest at birth, decreasing progressively during the first day of life (Dvorak 1972). Therefore, in a histological examination, where the amount of lipid substances observed is a rough expression of the amount of adrenocortical hormones, it would be expected that the normal newborn pig will have little or no lipids in the adrenal cortex, and that they would decrease with the length of gestation, as was observed in this material. The increase in the amount of lipids with age noted (Table 2 ), may be a sign of the reformation of hormones after birth.

From a morphological point of view, the activity of the thyroid gland is generally estimated by the shape and cytoplasmic content of the follicular cells, where the presence of cuboidal or columnar cells indicates high activity, and squamous cells a resting phase; by the number of vacuoles in the colloid; and by the amount and staining reaction of the colloid. The vacuoles, when first described by Anderson (1984) and Aron (1930), were considered to be fixation artifacts, since they are not found in freeze-dried specimens (De Roberties 1949). However, these "artifacts" apparently correspond to a property of an activated gland (Lebland 1949). In our material, the cells in the colloid containing follicles were of the columnar type, slightly higher than a strictly cuboidal cell type, with no or very little variation from case to case. Thus, in order to evaluate thyroid status in these animals, we attempted to estimate the amount of vacuoles in the follicles, the solid epithelial structure without lumina (to roughly establish the amount of follicles), and the amount of empty and apparently inactive follicles surrounded by a low epithelium with pyknotic nuclei. It was concluded from the histological examination that the appearance of the thyroid gland 
could vary greatly in clinically normal animals.

The pancreas is an organ where post mortem changes appear rather quickly after death. Even if necropsy is performed immediately after death, it is an important technical consideration that small portions of pancreas be fixed at a time, so the centre of the organ will be properly fixed. With this problem in mind, it is necessary to be careful when evaluating the histological pictures. In this material, the pancreas was removed relatively quickly after death, and the fixed pieces were small. The annotation "poor development of glandular tissues" therefore was not necessarily an expression of possible post mortem changes. Platt \& Stewart (1967) observed in older pigs suffering from experimentally induced calorie deficiency that the individual cells of the exocrine pancreas were small, and the acinar arrangement of the cells was missing. In pigs suffering from very severe deficiency, clumps of hyperchromatic nuclei, practically devoid of cytoplasm were observed. Since similar observations were made in the present material (Table 2, Fig. 13), it is possible that some of these changes occurred due to conditions existing at a stage prior to death.

\section{Acknowledgement}

This work was supported by Grant Nos. P111 och P139 from the Swedish University of Agricultural Sciences (J. Svendsen) and by Grant No. 6000 1-5 from the National Veterinary Institute (N.-E. Björklund).

\section{References}

Anderson $O A$ : Zur Kenntnis der Morphologie der Schilddrüse. (Studies on the morphology of the thyroid gland). Arc. Anat. Entw. Anat. Abth. 1984, 117, 225-268.

Anon.: A survey of the incidence and causes of mortality in pigs. I. Sow survey. Vet. Rec. 1959, 71, 777-786.

Aron $M$ : Indications apportées par la methode des injections hypophysaires sur le fonctionnement de la thyroide et ses tests morphologiques. (Studies on the function and morphology of the thyroid gland using injections with extracts from the hypophysis). Compte rende Soc. Biol. 1930, 103, 148-150.

Bengtsson $A-C$, Svendsen $J$, Persson $G$ : Jämförande undersökning av dräktiga suggor i 4 olika inhysningssystem: Beteendestudier och renhetsstudier. (Comparison of four types of housing for sows in gestation: Behaviour studies and hygiene studies). Report 36. Dept. Farm Buildings, Swedish Univ. Agric. Sci. Lund 1983.

Bille $N$, Nielsen $N C$, Larsen $J L$, Svendsen $J$ : Preweaning mortality in pigs. II. The perinatal period. Nord. Vet.-Med. 1974, 26, 294313.

Bischoff $M B$, Richter WR, Stein RJ: Ultrastructural changes in pig hepatocutes during the traditional period from late foetal to early neonatal life. J. Cell. Sci. 1969, 4, 381-395.

Björklund $N-E$, Svendsen J, Svendsen LS: Histomorphological studies of the perinatal pig: Comparison of five mortality groups with unaffected pigs. Acta vet. scand. 1987, 28, 105-116.

Bäckström L: Environment and animal health in piglet production. A field study of incidences and correlations. Thesis. Acta vet. scand. 1973, Suppl. 41, 1-240.

Coussement $W$, Ducatelle $R$, Hoorens J: Subcutaan oedeem by pasgeboren biggen. (Subcutaneous edema of the newborn pig). Vlaams Diergen. Tijdsch. 1983, 52, 209-219.

DeRoberties E: Cytological and cytochemical basis of thyroid function. Ann. N.Y. Acad. Sci. 1949, 50, 317-335.

DeRoth L, Downie HG: Evaluation of viability of neonatal swine. Canad. vet. J. 1976, 17, 275-279.

Dixon WJ \& Brown MB: (Editors). Biomedical Computer Programs, P. series, pp. 1-880, U.C.L.A. Press, Los Angeles 1977, revised 1983. 
Dominick MA, Carson TL: Effects of carbon monoxide exposure on pregnant sows and their fetuses. Amer. J. vet. res. 1983, 44, 3540.

Dvorák M: Adrenocortical function in foetal, neonatal and young pigs. J. Endocrinol. 1972, 54, 473-481.

Edwards BL: Oedema in new-born pigs. Vet. Rec. 1961, 73, 540-543.

Friis $C$ : Postnatal development of the pig kidney: Ultrastructure of the glomerolus and the proximal tubule. J. Anat. 1980, 130, 513-526.

Glastonbury JRW: Preweaning mortality in the pig. Pathological findings in piglets dying before and during partition. Austr. Vet. J. 1977, 53, 282-286.

Gracey JF: Survey of pig losses. Vet. Rec. 1955, 67, 984-990.

Hakkarainen J: Developmental changes of protein, RNA, DNA, lipid and glycogen in the liver, skeletal muscle and brain of the piglet. Acta vet. Scand. 1975, Suppl. 59, 1-198.

Jacobsen KAa: Håndbog for svinehold. (Manual in swine production). Landbrugets Informationskontor, Tune, 1972, p. 1-116.

Jeppsson M, Svendsen J, Andréasson B: Beteendestudier på lösgående och fixerade svinsuggor under samma skötsel-, utfodrings- och stallförhållanden. (Behaviour studies on loose and confined dry sows maintained under the same husbandry, feeding and stable conditions). Report 10. Dept. Farm Buildings. Swedish Univ. Agric. Sci., Lund 1980.

Kernkamp HCH: Birth and death statistics on pigs of preweaning age. J. Amer. vet. med. Ass. 1965, 145, 337-340.

Kito H, Hosada S: Triple staining for simultaneous visulization of cell types in islet of Langerhans of pancreas. Successive application of argyrophil, aldehyde-fuchsin and lead-hematoxylin stains in a single tissue section. J. Histochem. Cytochem. 1977, 25, 1010-1020.

Kühn M, Wesemeier H: Pathopenetische Schwerpunkte prä und neonataler Schädigungen beim Schwein. (Pathogenetic priorities of prenatal and neonatal damage to swine). Mh. Vet.-Med. 1984, 39, 551-555.

LeBland CP Cit. by Platt BS, Stewart RJW: 1967.
Leman AD, Knudson $C$, Rodeffer $H E$, Mueller $A G$ : Reproductive performance of swine on 76 Illinois farms. J. Amer. vet. med. Ass. 1972, 161, 1248-1250.

Miller ER, Ullrey DE, Ackerman I, Schmidt, DA, Luecke $R W$, Hoefer JA: Swine hematology from birth to maturity. II. Erythrocyte population, size and hemoglobin concentration. J. Anim. Sci. 1961, 20, 890-897.

Morrill CC: Studies on baby pig mortality. IX. Some morphological observations on the newborn pig, with special reference to hypoglycemia. Amer. J. vet. Res. 1952, 13, 171-180.

Nielsen NC, Christensen $K$, Bille $N$, Larsen JL: Preweaning mortality in pigs. I. Herd investigations. Nord. Vet.-Med. 1974, 26, 137-150.

Platt, BS, Stewart RJW: Experimental proteincaloric deficiency: Histopathological changes in the endocrine glands of pigs. J. Endocr. 1967, 38, 121-143.

Pomeroy $R W$ : Interfertility and neonatal mortality in the sow. I-IV. J. agric. Sci. 1960, 44, $1-66$.

Randall GCB: The relationship between arterial blood $\mathrm{pH}$ and $\mathrm{pCO}_{2}$ to the viability of the newborn piglet. Canad. J. comp. Med. 1971, 35, 141-146.

Shapiro HA: Microscopy of human fetal lung and the diagnosis of postnatal respiration. Legal Med. Annual 1976, 39-52 (cited in Excerpta Med. 1978, 44, Sect. 5, Abs. No. 1814).

Svendsen $J$, Bille $N$ : Reducing preweaning mortality. In: Diseases of Swine. 5th edition. Iowa State University Press. Ch. 67. Ames, Iowa 1981, pp. 729-736.

Svendsen $J$, Bengtsson A-C: Produktionssystem för smågrisuppfödning: Åtgärder för att reducera antalet klämda och trampade grisar. (Production systems for farrowing piglets: Methods for reducing the number of piglets traumatized by the sow). Konsulentavd. rapporter, Allmänt 39, Swedish Univ.Agric. Sci., Uppsala, 1982.

Svendsen $L S$ : Organ weights of the newborn pig. Characterization and comparison of the organ weights of pigs dying within 48 hours of birth with those of unaffected, growing pigs: Stillborn intra partum pigs, weak pigs, splayleg 
pigs, splayleg and weak (splayweak) pigs and traumatized pigs. Acta vet. scand. 1982, Suppl. 78, 1-205.

Svendsen $J$, Bengtsson $A-C$ : Produktionssystem för smågrisuppfödning: Någre resultat från 5 års jämförande undersökning av olika inhysningsystem för dräktiga och digivande suggor. (Housing systems in piglet production: Comparative results from 5 years of investigations into different housingsystems for sows in gestation and sows at farrowing). Konsulentavd. rapporter, Allmänt 46, Swedish Univ. Agric. Sci. 16:1-16:15, Lund, 1983.

Svendsen $J$, Svendsen LS, Bengtsson A-C: Reducing perinatal mortality. In "Diseases of Swine", Sixth Edition. Iowa State University Press, Ames, Iowa 1986, Ch. 71, pp. 813-825.

Waibl H: Quantitative Untersuchungen am Schweinethymus. (Quantitative studies on the thymus of the pig). Zbl. Vet. Med. C. 1982, 11, 234-241.

Valdè-Dapena $M H$ : Histology of the Fetus and Newborn, p. 57 and p. 335. W. B. Saunders Co., Philadelphia, 1979.

\author{
Sammanfattning \\ Histomorfologiska studier av grisar $i$ perinatala \\ perioden: den normala grisen.
}

I strävan att söka finna orsaker till perinatal dödlighet hos svin utfördes en histomorfologisk studie av organ från 0,4-60 timmar gamla avlivade normala grisar och från lika gamla perinatalt döda eller sjuka, dödade djur tillhörande olika mortalitetsgrupper. Hjärta, lunga, lever, njure, mjälte, thymus, pankreas, thyreoidea och binjurer studerades. Alla histologiska snitt undersöktes utan vetskap om respektive djurs dödsorsak. Graden av varierande observationer $i$ organen noterades enligt en skala 1 till 4 där 1 angav ingen eller obetydlig och 4 höggradig förekomst av respektive iakttagelser. Procenten organobservationer graderade 3-4 inom de studerade grupperna djur fastställdes och justerades med hjälp av kovariansanalys för den liniära effekten av total kroppsvikt (vid dödstillfället) ålder, dräktighetslängd, kullstorlek (alla födda grisar, levande eller döda). Denna första rapport beskriver iakttagelser hos avlivade normala djur.

(Received November 7, 1986).

Reprints may be requested from: J. Svendsen, Dept. of Farm Buildings, P. O. Box 624, S-220 06 Lund, Sweden. 